\title{
Effect of LSD on Prepulse Inhibition and Spontaneous Behavior in the Rat: A Pharmacological Analysis and Comparison between Two Rat Strains
}

\author{
A.-M. Ouagazzal, Ph.D., A.J. Grottick, Ph.D., J.-L. Moreau, Ph.D., and G.A. Higgins, Ph.D.
}

The goal of the present study was to better delineate the mechanisms of action of the prototypical hallucinogen LSD. LSD (0.03, 0.1 and $0.3 \mathrm{mg} / \mathrm{kg}$, s.c.) produced locomotor hyperactivity, disruption of PPI and a number of behaviors indicative of 5-HT activation such as wet-dog shakes, back muscle contractions and forepaw treading. These various behavioral effects of LSD were studied in both Sprague-Dawley and Wistar rats, although with the exception of back muscle contractions which were more prominent in Sprague-Dawley rats, no major strain differences were detected. The PPI disruption induced by LSD (0.1 mg/kg) in Sprague-Dawley rats was completely reversed by pretreatment with the selective 5- $\mathrm{HT}_{2 \mathrm{~A}}$ antagonist MDL 100907 (0.5 and $1 \mathrm{mg} / \mathrm{kg}$, s.c.). In contrast, pretreatment with antagonists at $5-H T_{2 C},(S B$
$242084(0.5 \mathrm{mg} / \mathrm{kg}$, i.p. $)) ; 5-H_{2 B / 2 C}(S D Z$ SER $082(1 \mathrm{mg} / \mathrm{kg}$, s.c.)); 5-HT ${ }_{1 A},((+)-W A Y 100135$ (1 and $20 \mathrm{mg} / \mathrm{kg}$, s.c.)) and 5- $\mathrm{HT}_{6}$ receptors, (RO 04-6790 (30 mg/kg, i.p.)), all failed to influence LSD-induced disruption of PPI. The dopamine $D A_{2 l i k e}$ receptor antagonist, haloperidol $(0.1$ and $0.2 \mathrm{mg} / \mathrm{kg}$, S.c.), was without effect against an LSD-induced disruption of PPI. Finally, selective blockade of $5-H_{2 A}$ but not $5-H T_{2 C}$ receptors completely abolished the locomotor hyperactivity induced by LSD. These findings provide empirical evidence to support the view that the hallucinogenic effects of LSD are mediated by a direct agonist effect at $5-\mathrm{HT}_{2 \mathrm{~A}}$ receptors.

[Neuropsychopharmacology 25:565-575, 2001]

(C) 2001 American College of Neuropsychopharmacology.

Published by Elsevier Science Inc.
KEY WORDS: 5- $\mathrm{HT}_{2}$ receptor; PPI; LSD; Hallucinogen

Delineation of the neurobiological mechanisms underlying the profound effects of hallucinogens on perception, mood, and thought processes has been the subject of

From the Pharmaceuticals Division, Preclinical Studies, F. Hoffmann-La Roche, Basel, Switzerland.

Address correspondence to: Dr. A. Ouagazzal, Institut de Génétique et de Biologie Moléculaire et Cellulaire, BP 163, 67404 Illkirch Cedex, France. Tel.: 33-388-653-383; Fax: 33-388-653-201; E-mail: abdel@igbmc.u-strasbg.fr

Received October 30, 2000; revised March 8, 2001; accepted April 25, 2001.

Online publication: $4 / 26 / 01$ at www.acnp.org/citations/ Npp042701114. great interest over the years. There is now increasing evidence that the two major classes of hallucinogens, the indolamines (e.g., LSD) and the phenethylamines (e.g., DOM and DOI) share a common site of action at $5-\mathrm{HT}_{2}$ receptor populations (Barnes and Sharp 1999; Aghajanian and Marek 2000). 5- $\mathrm{HT}_{2}$ receptors consist of three distinct subtypes, namely $5-\mathrm{HT}_{2 \mathrm{~A}}, 5-\mathrm{HT}_{2 \mathrm{~B}}$ and $5-\mathrm{HT}_{2 \mathrm{C}}$ (for review see Barnes and Sharp 1999). They are G-protein-coupled receptors and share a high degree of homology in their amino acid sequences. Binding and cellular studies have shown that LSD, DOI, DOM and other related hallucinogens share a high affinity for the $5-\mathrm{HT}_{2 \mathrm{~A} / \mathrm{B} / \mathrm{C}}$ receptor subtypes (Egan et al. 1998; Nelson et al. 1999; Porter et al. 1999). Furthermore, a strong 
correlation exists between their binding affinity at the $5-\mathrm{HT}_{2 \mathrm{~A} / \mathrm{B} / \mathrm{C}}$ receptor subtypes and their hallucinogenic potencies in man (for review see Barnes and Sharp 1999; Roth et al. 1999; Aghajanian and Marek 1999).

Until recently, study of the exact contribution of individual $5-\mathrm{HT}_{2}$ receptor subtypes to the behavioral profile of hallucinogens has been hampered by the lack of selective ligands. The recent development of selective ligands for $5-\mathrm{HT}_{2 \mathrm{~A}}$ and $5-\mathrm{HT}_{2 \mathrm{C}}$ receptor subtypes has provided the opportunity for a more precise investigation into their functional role. The $5-\mathrm{HT}_{2 \mathrm{~A}}$ receptor antagonist MDL 100907 has been reported to have at least 100-fold selectivity for $5-\mathrm{HT}_{2 \mathrm{~A}}$ over the $5-\mathrm{HT}_{2 \mathrm{C}}$ receptor (Palfreyman et al. 1993; Kehne et al. 1996). The 5- $\mathrm{HT}_{2 \mathrm{C}}$ receptor antagonist SB 242084 has 100-fold selectivity for the 5- $\mathrm{HT}_{2 \mathrm{C}}$ over both $5-\mathrm{HT}_{2 \mathrm{~A}}$ and $5-\mathrm{HT}_{2 \mathrm{~B}}$ receptors (Bromidge et al. 1997; Kennett et al. 1997). On the other hand, the 5- $\mathrm{HT}_{2 \mathrm{C} / 2 \mathrm{~B}}$ receptor antagonist SDZ SER 082 displays 40 -fold selectivity for the $5-\mathrm{HT}_{2 \mathrm{C}}$ compared to the $5-\mathrm{HT}_{2 \mathrm{~A}}$ receptor, but similar affinity for the $5-\mathrm{HT}_{2 \mathrm{C}}$ and $5-\mathrm{HT}_{2 \mathrm{~B}}$ receptor subtypes (Nozulak et al. 1995). Studies conducted with some of these $5-\mathrm{HT}_{2}$ subtypeselective antagonists have indicated that $5-\mathrm{HT}_{2 \mathrm{~A}}$ rather than $5-\mathrm{HT}_{2 \mathrm{C}}$ receptor subtypes are crucial for the discriminative stimulus effects of DOI (Schreiber et al. 1994). $5-\mathrm{HT}_{2 \mathrm{~A}}$ receptor activation was also suggested to be the principal mechanism underlying the disruptive effects of DOI on prepulse inhibition and latent inhibition (Sipes and Geyer 1995; Padich et al. 1996; Hitchcock et al. 1997). Furthermore, it has been shown that a number of 5-HT behaviors evoked by DOI in rats, such as wet-dog shakes, forepaw treading and back muscle contractions are mediated by $5-\mathrm{HT}_{2 \mathrm{~A}}$ rather than $5-\mathrm{HT}_{2 \mathrm{C}}$ receptors (Wettstein et al. 1999; Sánchez and Arnt 2000).

While there is compelling evidence that $5-\mathrm{HT}_{2 \mathrm{~A}}$ receptor subtypes are the principal sites of action for DOI, to the best of our knowledge little is known about the participation of $5-\mathrm{HT}_{2 \mathrm{~A}}$ or $5-\mathrm{HT}_{2 \mathrm{C}}$ receptors in the mediation of the behavioral effects of LSD. This is partly due to the fact that most of the recent behavioral studies have typically focused on DOI, which shares many properties with LSD but has a less complicated pharmacology. Indeed, unlike DOI which displays a high selectivity for $5-\mathrm{HT}_{2}$ receptors, $\mathrm{LSD}$ interacts additionally with several 5-HT (e.g., 5- $\mathrm{HT}_{1 \mathrm{~A}}, 5-\mathrm{HT}_{5}, 5-\mathrm{HT}_{6}$ and 5- $\mathrm{HT}_{7}$ ) and dopamine $\mathrm{D}_{2 \text { like }}$ receptors (Creese et al. 1975; Plassat et al. 1992; Shen et al. 1993; Boess et al. 1997; Aghajanian and Marek 1999). Early studies using correlational analysis to drug discrimination assays has suggested both $5-\mathrm{HT}_{2 \mathrm{~A}}$ and $5-\mathrm{HT}_{2 \mathrm{C}}$ receptors may be important for the stimulus effects of LSD (Titeler et al. 1988), although more recently the potency of a number of antagonists to reduce the discriminative stimulus effects of LSD was shown to be significantly correlated with $5-\mathrm{HT}_{2 \mathrm{~A}}$ rather than $5-\mathrm{HT}_{2 \mathrm{C}}$ affinity (Fiorella et al. 1995). LSD was also reported to produce a biphasic change in locomotion, which consisted of an initial decrease followed by an increase in locomotor and exploratory behavior (Adams and Geyer 1982). More importantly, although the initial suppression of investigatory behaviors produced by LSD and DOI in rat is similar, it is differentially influenced by $5-\mathrm{HT}_{2 \mathrm{~A}}$ and $5-\mathrm{HT}_{2 \mathrm{C}}$ receptors (Krebs-Thomson et al. 1998). These findings suggest that at least in terms of locomotor activity, the mechanisms of action of DOI and LSD might not be identical (see also Mittman and Geyer 1991).

In light of the above findings, the present study attempted to clarify further the pharmacological profile of LSD on PPI and locomotion. In the first series of experiments we characterized the behavioral profile of LSD in two commonly used rat strains, namely Sprague-Dawley and Wistar. Previous studies have shown that Sprague-Dawley and Wistar rats display different sensitivity to psychotomimetics (e.g., apomorphine, amphetamine and PCP) (Varty and Higgins 1994; Kinney et al. 1999) and antipsychotics (e.g., clozapine and risperidone) (Swerdlow et al. 1998; Varty et al. 1999), and thus it seemed worthwhile to examine whether they might show differential sensitivity to LSD. We first compared the effects of systemic administration of LSD on PPI and locomotor activity in both strains. In addition, we examined whether LSD could produce behavioral signs (wet-dog shakes, forepaw treading, back muscle contractions, penile erections/grooming) in Sprague-Dawley and Wistar rats, similar to that attributed to $5-\mathrm{HT}_{2 \mathrm{~A}}$ or $5-\mathrm{HT}_{2 \mathrm{C}}$ receptor activation (Millan et al. 1997; Martin et al. 1998; Wettstein et al. 1999). Finally we studied the respective role of $5-\mathrm{HT}_{2 \mathrm{~A}}$ and $5-\mathrm{HT}_{2 \mathrm{C}}$ receptors in the mediation of PPI deficits and locomotor hyperactivity produced by LSD in Sprague-Dawley rats using the most selective $5-\mathrm{HT}_{2 \mathrm{~A}}$ and $5-\mathrm{HT}_{2 \mathrm{C}}$ receptor antagonists currently available. Given that LSD interacts with 5- $\mathrm{HT}_{1 \mathrm{~A}}, 5-\mathrm{HT}_{6}$ and dopamine $\mathrm{D}_{2 \text { like }}$ receptors, we also examined whether these receptors might contribute to the PPI deficits induced by LSD.

\section{METHODS}

\section{Animals}

Adult male (280-300g) Sprague-Dawley and Wistar rats (RCC Ltd., Fullinsdorf, Switzerland) were used. Following arrival at the holding facility, the animals were housed 4 per cage in a light and temperature controlled environment (lights on: 6 A.M.-6 P.M.) with food available ad-libitum. They were allowed one week of acclimation prior to testing. Experiments took place between 8 A.M. and 6 P.M..

\section{Apparatus}

Prepulse inhibition. Testing was conducted in eight startle devices (SRLAB, San Diego Instruments, San Di- 
ego, California, USA) each consisting of a Plexiglas cylinder $(8.8 \mathrm{~cm}$ diameter $)$ mounted on a Plexiglas platform in a ventilated, sound-attenuated cubicle with a high frequency loudspeaker $(28 \mathrm{~cm}$ above the cylinder) producing all acoustic stimuli. The background noise of each chamber was $68 \mathrm{~dB}$. Movements within the cylinder were detected and transduced by a piezoelectric accelerometer attached to the Plexiglas base, digitized and stored by a computer. Beginning at the stimulus onset, 150 1-ms readings were recorded to obtain startle amplitude.

Locomotor activity and behavioral observations. Locomotor activity was measured using automated activity cages $(36 \times 24 \times 19, \mathrm{~L} \times \mathrm{W} \times \mathrm{H}$; Benwick Electronics, UK). Each cage was fitted with two sets of 19 infrared beams ( 12 front to back and 7 side to side with 2.5 $\mathrm{cm}$ space between two successive beams) located 5 and $15 \mathrm{~cm}$ off the cage floor. The activity detector operates by counting the number of times the beams changes from unbroken to broken (or vice versa) and incrementing the relevant counters. The interruption of the lower and upper sets of beams provided automated measures of horizontal and vertical activity, respectively. Noncumulative records of photocell beam interruptions, for individual rats, were taken every five minutes in each experimental session. Mobile counts (interruption of three successive beams of the lower set of beams) were used to measure locomotor activity of the animals. For direct observations, the rats were placed individually in Macrolon cages $(26 \times 10 \times 30 \mathrm{~cm}, \mathrm{~L} \times \mathrm{W} \times \mathrm{H})$ with sawdust bedding. Mirrors placed behind the cages permitted an all-round view of the rats. Up to six rats were simultaneously scored by an observer blind to drug treatments.

\section{Drugs}

LSD, MDL 100907, SDZ SER 082, (+)-WAY 100135, RO 04-6790, and haloperidol (synthesized at Roche) were dissolved in $\mathrm{NaCl} 0.9 \%$ containing $0.3 \%$ Tween. SB 242084 was dissolved in $8 \%$ HP- $\beta$-cyclodextrin with $25 \mathrm{mM}$ citric acid. MDL 100907, SDZ SER 082 and (+)WAY 100135 were administered subcutaneously (s.c.) 30 minutes before the test. LSD and haloperidol were administered s.c. 5 and 10 minutes before the test, respectively. SB 242084 was given intraperitoneally (i.p.) 30 minutes before the test. All drugs were administered in a dose volume of $1 \mathrm{ml} / \mathrm{kg}$.

\section{General Procedure}

The experimental procedures used in this study received approval from a local committee based on adherence to Swiss federal regulations and guidelines on animal experimentation.
Prepulse Inhibition. Prior to drug testing, the rats were each exposed to a single PPI session (identical to that used in experiment II) in order to ensure that the animals were assigned into balanced groups based on equivalent startle and PPI. For drug studies, the rats were used twice with a period of at least five days between two successive tests.

Experiment I. Naïve rats of each strain, Sprague-Dawley and Wistar, were tested in these series of experiments. Animals were given a subcutaneous injection of $\operatorname{LSD}(0.03,0.1$ and $0.3 \mathrm{mg} / \mathrm{kg}, \mathrm{n}=8$ per dose) or vehicle ( $\mathrm{NaCl} 0.9 \%$ containing $0.3 \%$ Tween), and 5 minutes later they were tested in a PPI paradigm. Each session was initiated with a 5-min acclimation period followed by 10 successive $120 \mathrm{~dB}$ trials. These trials were not included in the final data analysis. Eight different trial types were then presented: Startle pulse (ST120, 120 $\mathrm{dB} / 40$ msec duration), three prepulse stimulus given alone (70, 75 and $80 \mathrm{~dB} / 20$ msec duration: P70, P75 and P80 respectively), P70, P75 and P80 given $100 \mathrm{~ms}$ before the onset of the startle pulse (PP70, PP75 and PP80, respectively), and finally a trial where only the background noise $(68 \mathrm{~dB})$ was presented (NST) in order to measure the baseline movement in the cylinders. All trials were applied 8 times and presented in random order. The average inter-trial interval (ITI) was $15 \mathrm{sec}$ (range 10-20 s).

Experiment II. Only Sprague-Dawley rats were used in these series of experiments. Animals were pretreated with MDL 100907 ( 1 and $0.5 \mathrm{mg} / \mathrm{kg}, \mathrm{n}=7$ per dose), SB $242084(0.5 \mathrm{mg} / \mathrm{kg}, \mathrm{n}=8)$, SDZ SER $082(1 \mathrm{mg} / \mathrm{kg}, \mathrm{n}=$ 8), (+)-WAY 100135 ( 1 and $20 \mathrm{mg} / \mathrm{kg}, \mathrm{n}=8$ per dose), $\mathrm{RO} 04-6790$ (30 mg/kg, $\mathrm{n}=8$ ) or haloperidol (0.1 and $0.2 \mathrm{mg} / \mathrm{kg}, \mathrm{n}=8$ per dose) alone or in combination with LSD (0.1 mg $/ \mathrm{kg} \mathrm{n}=6-8$ per group) according to a $2 \times 2$ factorial design. Control groups received injections of the corresponding vehicles for each treatment ( $n=6-8$ per group). Each PPI session was initiated with a 5 -min acclimation period followed by 10 successive $120 \mathrm{~dB}$ trials. These trials were not included in the analysis. Four different trial types were then presented: Startle pulse (ST120, $120 \mathrm{~dB} / 40 \mathrm{msec}$ ), prepulse stimulus given alone (P75, $75 \mathrm{~dB} / 20 \mathrm{~ms}$ ), P75 given $100 \mathrm{~ms}$ before the onset of the startle pulse (PP75), and finally a trial where only the background noise $(68 \mathrm{~dB})$ was presented (NST) in order to measure the baseline movement in the cylinders. All trials were applied 10 times and presented in random order. The average inter-trial interval (ITI) was $15 \mathrm{sec}$ (range 10-20 s).

\section{Locomotor Activity and Behavioral Observations}

Experiment I. Thirty-six naïve rats of each strain, Sprague-Dawley and Wistar, were used. Animals were first familiarized with the experimental cages for 60 minutes prior to any drug treatment. After habituation, 
they received a subcutaneous injection of $\operatorname{LSD}(0.03,0.1$ and $0.3 \mathrm{mg} / \mathrm{kg}, \mathrm{n}=8$ per dose) and their locomotor activity was measured 5 minutes later for 60 minutes.

Experiment II. A further group of experimentally naïve Sprague-Dawley rats were pretreated with an injection of MDL $100907(0.5 \mathrm{mg} / \mathrm{kg}$, s.c., $\mathrm{n}=8)$ or SB $242084(0.5 \mathrm{mg} / \mathrm{kg}$, i.p., $\mathrm{n}=8)$ alone or in combination with LSD $(0.1 \mathrm{mg} / \mathrm{kg}, \mathrm{n}=8$ per group). Control groups received injections of the corresponding vehicles for each treatment ( $\mathrm{n}=8$ per group). The locomotor activity test started 5 minutes after LSD administration and lasted for 60 minutes.

Experiment III. One week after the locomotor activity study (Experiment I), animals were randomly allocated to vehicle and $\operatorname{LSD}(0.03,0.1$ and $0.3 \mathrm{mg} / \mathrm{kg}, \mathrm{n}=8$ per dose) groups. The incidence of penile erection, penile grooming, wet-dog shakes and back muscle contractions was scored continuously during the $60-\mathrm{min}$ session. The presence or absence of forepaw treading and chewing was also scored for 60 minutes in blocks of 5-min intervals. All scores were cumulated for the whole session, i.e. a maximal score per animal is 12 .

\section{Statistical Analysis}

Effects of LSD on PPI were analyzed using a 3-way ANOVA with strain and LSD treatment as a betweensubjects factor and trials (PP70, PP75 and PP80) as the repeated measure. Mean startle magnitude from the 120 $\mathrm{dB}$ trial, locomotor activity (mobile counts) and the 5-HT behaviors, wet-dog shakes, penile grooming and back muscle contractions, were analyzed using 2-way ANOVA with strain and LSD dose as between-subject factor. Forepaw treading and chewing were analyzed as medians and interquartile range with group comparisons made by Mann-Whitney U-test following a significant main effect according to the Kruskal-Wallis test. Drug interaction data were analyzed using a 2-way ANOVA with LSD and challenge drug as between-subject factors. Individual comparisons were carried out using Newman-Keuls post-hoc test whenever the ANOVA indicated statistically significant main effect or interaction. The \% PPI was determined according to the formula (100 × (ST120- PP70, PP75 or PP80)/ST120).

\section{RESULTS}

\section{Behavioral Profile of LSD in Sprague-Dawley and Wistar rats}

Prepulse Inhibition. LSD (0.03, 0.1 and $0.3 \mathrm{mg} / \mathrm{kg}$ ) dose-dependently disrupted PPI in Sprague-Dawley and Wistar rats (main effect of treatment: $\mathrm{F}_{3,55}=15.5, p<$ .001 ; treatment $\mathrm{X}$ trials interaction $\mathrm{F}_{6,110}=5.2, p<.001$; Figure 1, Panel A). The 3-way ANOVA failed however to reveal a significant main effect of strain $\left(\mathrm{F}_{1,55}=2.1\right.$,
NS), strain $X$ treatment interaction $\left(\mathrm{F}_{3,55}=0.9, \mathrm{NS}\right)$ or strain $X$ treatment $X$ trial interaction $\left(\mathrm{F}_{6,110}=0.7, \mathrm{NS}\right)$, thus indicating that LSD had comparable effects on PPI in both strains. Post hoc tests at each trial type indicated that the two highest doses of LSD $(0.1$ and $0.3 \mathrm{mg})$ significantly disrupted PPI at both 75 and $80 \mathrm{~dB}$ prepulse intensities in Sprague-Dawley rats. In Wistar rats, all doses of LSD (0.03, 0.1 and $0.3 \mathrm{mg}$ ) significantly reduced PPI at the $75 \mathrm{~dB}$ prepulse intensity, in contrast, only the two highest doses had a significant effect on PPI at the $80 \mathrm{~dB}$ prepulse intensity $(p<.05$, Student Newman Keuls).

Wistar rats displayed a significantly higher startle response to the $120 \mathrm{~dB}$ pulse than Sprague-Dawley rats $\left(\mathrm{F}_{1,55}=64.4, p<.001\right.$, Figure 1, Panel B). Administration of LSD reduced startle reactivity in Sprague-Dawley rats $\left(\mathrm{F}_{3,55}=4.2, p<.05\right)$, and post hoc tests indicated that only the highest dose $(0.3 \mathrm{mg} / \mathrm{kg})$ had a significant effect (Figure 1, Panel B). In contrast, none of the doses of LSD significantly reduced the baseline startle magnitude in Wistar rats, although there was a clear trend at the $0.3 \mathrm{mg} / \mathrm{kg}$ dose. Consequently, no strain differences in the ability of LSD to reduce the baseline startle magnitude were detected (strain $\mathrm{X}$ treatment interaction: $\left(\mathrm{F}_{3,55}=2.6, \mathrm{NS}\right)$,

Locomotor Activity. LSD (0.03, 0.1 and $0.3 \mathrm{mg} / \mathrm{kg}$ ) markedly increased locomotor activity in SpragueDawley and Wistar rats (Figure 1, Panel C). The increase in locomotion was evident immediately during the first 5-min interval, and reached a maximum during the first 15-20 minutes of the test session. A gradual return to the control values was then noted during the second half of the test session depending on the dose. The 2-way ANOVA revealed a significant main effect of $\operatorname{LSD}\left(\mathrm{F}_{3,56}=15.8, p<.001\right)$, and post hoc tests indicated that all doses of LSD $(0.03,0.1$ and $0.3 \mathrm{mg} / \mathrm{kg})$ significantly increased locomotor activity in both strains. The 2-way ANOVA failed however to reveal a strain difference in response to the locomotor stimulant effects of LSD (main strain effects: $F_{1,56}=1.3$, NS; and strain $X$ LSD interaction: $\mathrm{F}_{3,42}=0.6, \mathrm{NS}$ ).

Behavioral Observations. Administration of LSDinduced various behavioral effects in Sprague-Dawley and Wistar rats that essentially consisted of wet-dog shakes and back muscle contractions, with occasional forepaw treading and chewing (Table 1). The 2-way ANOVA revealed a significant increase in the incidence of wet-dog shakes in both strains (main treatment effect: $\left.\mathrm{F}_{3,56}=10.0, p<.001\right)$, and post hoc tests indicated that only the two lower doses of LSD (0.03 and $0.1 \mathrm{mg})$ had a significant effect in Sprague-Dawley rats. In contrast, all doses of LSD significantly increased the incidence of wet-dog shakes in Wistar rats. However, no significant differences in the effects of LSD on wet-dog shakes were detected between the two strains (strain $\mathrm{X}$ 
Sprague-Dawley Rats
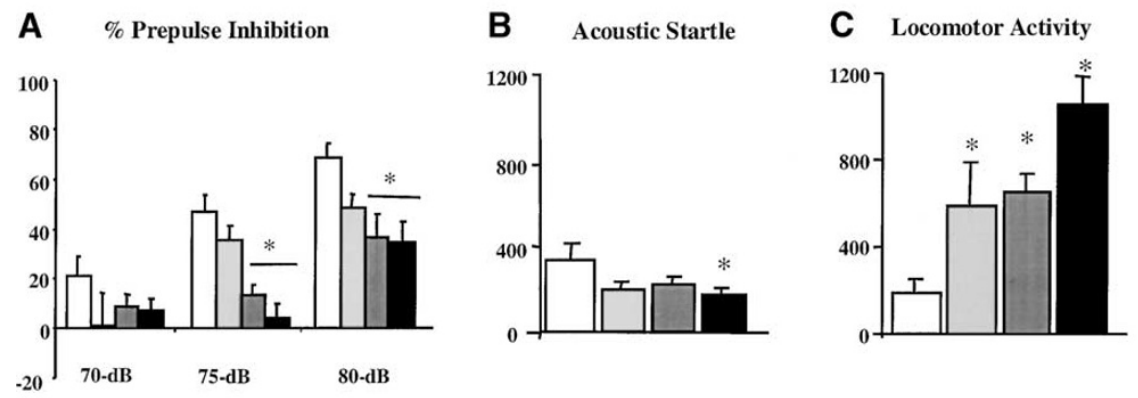

\section{Wistar Rats}
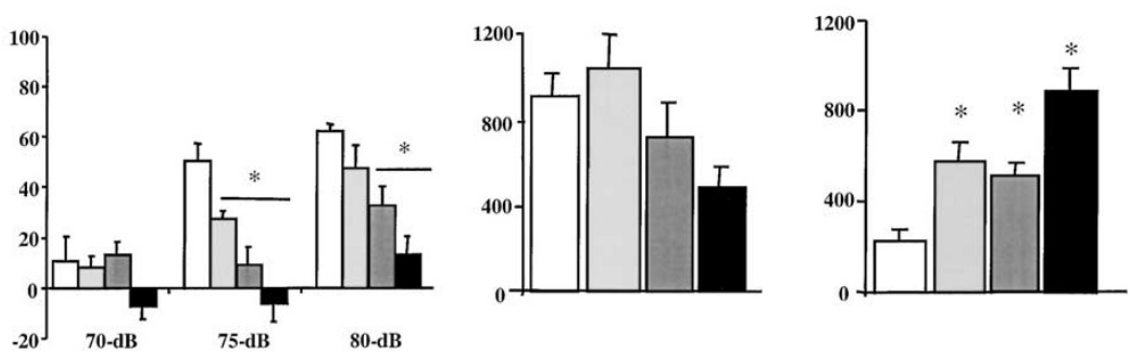

Figure 1. Effects of $\operatorname{LSD}(0.03,0.1$ and $0.3 \mathrm{mg} / \mathrm{kg}$, s.c.) on (A) prepulse inhibition, (B) acoustic startle, and (C) locomotor activity in Sprague-Dawley and Wistar rats. Values represent mean \pm S.E.M. for each group. $\mathrm{n}=7-8$ per group. ${ }^{*} p<.05$, significantly different from vehicle-treated animals. Open bars: vehicle treatments; gray bars: LSD $0.03 \mathrm{mg} / \mathrm{kg}$; crossed bars: LSD $0.1 \mathrm{mg} / \mathrm{kg}$; black bars: LSD $0.3 \mathrm{mg} / \mathrm{kg}$.

LSD interaction: $\mathrm{F}_{3,56}=2.5$, NS). LSD also induced back muscle contractions, and significant effects were detected at the highest dose $(0.3 \mathrm{mg} / \mathrm{kg})$ in both strains. However, there was a clear strain difference in the incidence of back muscle contractions produced by LSD as indicated by a significant main effect of strain $\left(\mathrm{F}_{3,56}=\right.$ $17.5, p<.001)$ and strain X LSD interaction $\left(\mathrm{F}_{3,56}=10.2\right.$, $p<.001)$. Significant increases in forepaw treading and chewing behaviors were also observed in both strains following administration of LSD $(p<.05$, Kruskal-Wallis test). In Sprague-Dawley rats, LSD had significant effects at the two highest doses $(0.1$ and $0.3 \mathrm{mg} / \mathrm{kg})$ on forepaw treading and significant effects at all doses on chewing ( $p<.05$, Mann-Whitney U-test). In Wistar rats, only $0.3 \mathrm{mg} / \mathrm{kg}$ LSD significantly increased forepaw treading, but the two highest doses $(0.1$ and $0.3 \mathrm{mg} / \mathrm{kg})$ had significant effects on chewing $(p<.05$, Mann-Whitney U-test). In neither Wister nor Sprague-Dawley rats was any notable change in penile erection/grooming identified following LSD pretreatment (Table 1).

\section{Drug Interaction Studies}

Effect of 5-HT Receptor Antagonists against an LSD (0.1 Mg/Kg)-Induced PPI Disruption in Sprague-Dawley Rats. In all experiments, LSD $(0.1 \mathrm{mg} / \mathrm{kg})$ significantly disrupted PPI in Sprague-Dawley rats. Pretreatment with MDL $100907(1 \mathrm{mg} / \mathrm{kg})$ alone induced a facilitation of PPI $\left(\mathrm{F}_{1,27}=24.2, p<.001\right.$, Figure 2, Panel A) MDL 100907 also reversed the disruption of PPI pro- duced by LSD but the 2-way ANOVA just failed to reveal a significant interaction between MDL 100907 and LSD $\left(\mathrm{F}_{1,27}=4.0, p=.06\right)$. Neither drug treatment altered the baseline startle amplitude (Table 2). Because pretreatment with MDL $100907(1 \mathrm{mg} / \mathrm{kg})$ alone affected PPI, a lower dose $(0.5 \mathrm{mg} / \mathrm{kg})$ was tested. MDL $100907(0.5 \mathrm{mg} / \mathrm{kg})$ administered alone had no effects on basal PPI but prevented the PPI deficit induced by LSD (MDL 100907 X LSD interaction, $\mathrm{F}_{1,23}=11.0, p<$ .05; Figure 2, Panel B). In this experiment, LSD significantly reduced the baseline startle amplitude $\left(\mathrm{F}_{1,23}=\right.$ 7.4, $p<.05)$ and the pretreatment with MDL 100907 failed to influence this effect (MDL 100907 X LSD interaction, $\mathrm{F}_{1,23}=0.1, p>.05$; Table 2).

Pretreatment with the selective 5- $\mathrm{HT}_{2 \mathrm{C}}$ receptor antagonist SB $242084(0.5 \mathrm{mg} / \mathrm{kg})$ was without any effect on basal PPI $\left(\mathrm{F}_{1,27}=1.6\right.$, NS, Figure 2, Panel C). SB 242084 also failed to reverse LSD-induced disruption of PPI as indicated by the lack of a significant SB 242084 X LSD interaction $\left(\mathrm{F}_{1,27}=3.6, \mathrm{NS}\right)$. Administration of LSD alone significantly decreased the baseline startle amplitude, $\left(\mathrm{F}_{1,27}=\right.$ 26.7, $p<.001$; Table 2). Even though SB 242084 significantly enhanced the startle reactivity $\left(\mathrm{F}_{1,27}=7.8, p<.01\right)$, it failed to reverse the effect of LSD on this measure.

Pretreatment with the 5- $\mathrm{HT}_{2 \mathrm{~B} / \mathrm{C}}$ antagonist SDZ SER $082(1 \mathrm{mg} / \mathrm{kg})$ alone had no effect on basal PPI $\left(\mathrm{F}_{1,27}=\right.$ 0.2 , NS, Figure 3, Panel D), and also failed to reverse LSD-induced disruption of PPI (SDZ SER 082 X LSD interaction, $\left.\mathrm{F}_{1,27}=0.4, \mathrm{NS}\right)$. As shown in Table 2, adminis- 
Table 1. Behavioral syndromes (Mean \pm SEM or Median and Interquartile range) induced by LSD (mg/kg) in SpragueDawley and Wistar Rats

\begin{tabular}{|c|c|c|c|c|c|c|}
\hline & & $\begin{array}{l}\text { Wet dog } \\
\text { shakes }\end{array}$ & $\begin{array}{l}\text { Back muscle } \\
\text { contractions }\end{array}$ & $\begin{array}{l}\text { Forepaw } \\
\text { Treading }\end{array}$ & Chewing & $\begin{array}{c}\text { Penile } \\
\text { grooming }\end{array}$ \\
\hline \multirow[t]{4}{*}{ Sprague-Dawley } & Vehicle & $1 \pm 0$ & $0 \pm 0$ & $0(0-0)$ & $1(0-3)$ & $1.4 \pm 0.3$ \\
\hline & $0.03 \mathrm{mg} / \mathrm{kg}$ & $12 \pm 3^{*}$ & $4 \pm 4$ & $0(0-2)$ & $5(4-7)^{*}$ & $0.5 \pm 0.3$ \\
\hline & $0.1 \mathrm{mg} / \mathrm{kg}$ & $11 \pm 4^{*}$ & $3 \pm 2$ & $1(1-2)^{*}$ & $7(7-8)^{*}$ & $0.3 \pm 0.2$ \\
\hline & $0.3 \mathrm{mg} / \mathrm{kg}$ & $8 \pm 2$ & $28 \pm 7^{*+}$ & $2(1-4)^{*}$ & $5(4-5)^{*}$ & $0 \pm 0$ \\
\hline \multirow[t]{4}{*}{ Wistar } & Vehicle & $1 \pm 1$ & $0 \pm 0$ & $0(0-0)$ & $3(1-3)$ & $0.3 \pm 0.2$ \\
\hline & $0.03 \mathrm{mg} / \mathrm{kg}$ & $7 \pm 1$ & $0 \pm 0$ & $0(0-0)$ & $4(3-5)$ & $1.5 \pm 0.4$ \\
\hline & $0.1 \mathrm{mg} / \mathrm{kg}$ & $13 \pm 1^{*}$ & $1 \pm 0$ & $1(0-1)$ & $6(5-6)^{*}$ & $1.5 \pm 0.5$ \\
\hline & $0.3 \mathrm{mg} / \mathrm{kg}$ & $15 \pm 3^{*}$ & $2 \pm 1^{*}$ & $3(3-5)^{*}$ & $7(6-9)^{*}$ & $1.3 \pm 0.5$ \\
\hline
\end{tabular}

${ }^{*} p<.05$, significantly different from vehicle-treated animals, Student Newman Keuls or Mann-Whitney U tests. ${ }^{+} p<.05$, significantly different from Wistar rats. $n=8$ rats per treatment group.

tration of LSD significantly reduced the baseline startle amplitude $\left(\mathrm{F}_{1,27}=7.0, p<.05\right)$, and pretreatment with SDZ SER 082 failed to reverse this effect $\left(\mathrm{F}_{1,27}=0.02, \mathrm{NS}\right)$.

Effect of 5-HT $\mathrm{T}_{1 A}, 5-\mathrm{HT}_{6}$ and $\mathrm{DA}_{2 \text { like }}$ Receptor Antagonists against an LSD-Induced PPI Disruption in Sprague-Dawley Rats. Pretreatment with the selective $5-\mathrm{HT}_{1 \mathrm{~A}}$ receptor antagonist (+)-WAY 100135 (1 and 20 $\mathrm{mg} / \mathrm{kg}$ ) had no effects on basal PPI, and also failed to antagonize an LSD-induced disruption of PPI (Figure 3, Panels A and B). The 2-way ANOVA failed to indicate a significant main effect of (+)-WAY $100135(1 \mathrm{mg} / \mathrm{kg}$ : $\left.\mathrm{F}_{1,28}=0.2, \mathrm{NS} ; 20 \mathrm{mg} / \mathrm{kg}: \mathrm{F}_{1,28}=0.1, \mathrm{NS}\right)$ or significant $(+)$-WAY $100135 \times$ LSD interaction $\left(1 \mathrm{mg} / \mathrm{kg}: \mathrm{F}_{1,28}=\right.$ 0.8 , NS; $\left.20 \mathrm{mg} / \mathrm{kg}: \mathrm{F}_{1,28}=0.5, \mathrm{NS}\right)$. None of the drug treatments affected startle reactivity (Table 2).

Pretreatment with the selective $5-\mathrm{HT}_{6}$ antagonist $\mathrm{RO}$ 04-6790 $(30 \mathrm{mg} / \mathrm{kg})$ had no effect on basal PPI $\left(\mathrm{F}_{1,28}=\right.$ $0.03, \mathrm{NS})$, and also failed to influence LSD-induced disruption of PPI $\left(\mathrm{F}_{1,28}=0.03, \mathrm{NS}\right.$, Figure 3, Panel C). None of the drug treatments affected basal startle (Table 2).

The dopamine $\mathrm{D}_{\text {2-like }}$ receptor antagonist, haloperidol $(0.1$ and $0.2 \mathrm{mg} / \mathrm{kg})$, also failed to affect basal PPI or reverse the effect of LSD (Figure 3, Panels E and F). The 2-way ANOVA failed to show a significant main effect of haloperidol ( $0.1 \mathrm{mg} / \mathrm{kg}: \mathrm{F}_{1,27}=0.9, \mathrm{NS} ; 0.2 \mathrm{mg} / \mathrm{kg}: \mathrm{F}_{1,25}=$ $0.1, \mathrm{NS}$ ) or significant haloperidol $\mathrm{X}$ LSD interaction $\left(0.1 \mathrm{mg} / \mathrm{kg}: \mathrm{F}_{1,27}=0.0, \mathrm{NS} ; 0.2 \mathrm{mg} / \mathrm{kg}: \mathrm{F}_{1,25}=1.0, \mathrm{NS}\right)$. Haloperidol $(0.1 \mathrm{mg} / \mathrm{kg})$ significantly reduced the baseline startle response $\left(\mathrm{F}_{1,27}=4.8, p<.05\right)$. In this experiment, LSD had no effects on baseline startle $\left(\mathrm{F}_{1,27}=0.2\right.$, NS), and also failed to influence the startle reduction induced by haloperidol (haloperidol X LSD interaction: $\mathrm{F}_{1,27}=0.8$, NS, Table 2). Again, haloperidol $(0.2 \mathrm{mg} / \mathrm{kg})$ significantly reduced baseline startle $\left(\mathrm{F}_{1,25}=4.7, p<\right.$ .05). In this experiment, the startle response was also reduced by $\operatorname{LSD}\left(\mathrm{F}_{1,25}=9.3, p<.05\right)$. The 2-way ANOVA failed to reveal any significant haloperidol X LSD interaction $\left(\mathrm{F}_{1,25}=2.3\right.$, NS).

Effect of $5-\mathrm{HT}_{2}$ receptor antagonists against LSDinduced locomotor hyperactivity in Sprague-Dawley rats. Figure 4 illustrates the effects of the selective $5-\mathrm{HT}_{2 \mathrm{~A}}$ and 5- $\mathrm{HT}_{2 \mathrm{C}}$ receptor antagonists MDL 100907 (0.5 mg/ $\mathrm{kg})$ and SB $242084(0.5 \mathrm{mg} / \mathrm{kg})$, respectively, on the locomotor hyperactivity induced by LSD. Administration of LSD $(0.1 \mathrm{mg} / \mathrm{kg})$ alone increased locomotor hyperactivity while pretreatment with MDL 100907 or SB
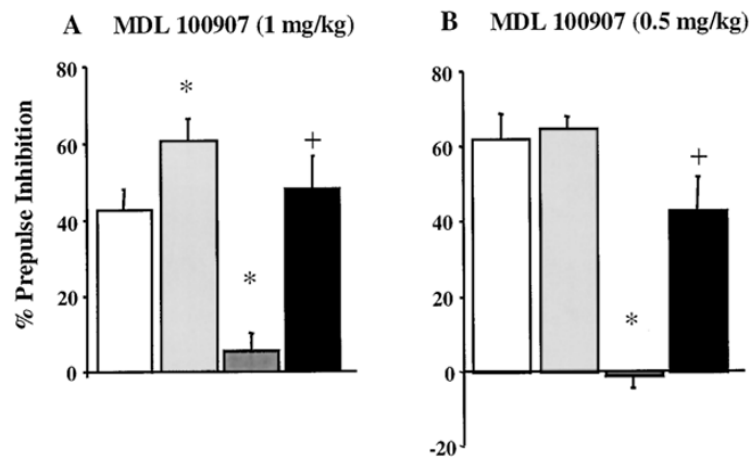

C SB $242084(0.5 \mathrm{mg} / \mathrm{kg})$

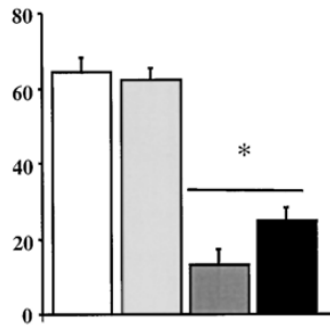

Figure 2. Effects of MDL 100907 (0.5 and $1 \mathrm{mg} / \mathrm{kg}$, s.c.) and SB 242084 (0.5 mg/kg, i.p.) on the disruption of PPI induced by LSD $\left(0.1 \mathrm{mg} / \mathrm{kg}\right.$, s.c.) in Sprague-Dawley rats. Values represent mean \pm S.E.M. for each group. $\mathrm{n}=6-8$ per group. ${ }^{*} p<.05$, significantly different from vehicle-treated animals, and $+p<.05$, significantly different from LSD-treated animals. Open bars: vehicle/vehicle treatments; gray bars: drug/vehicle treatments; crossed bars: vehicle/LSD treatments; black bars: drug/LSD treatments. 
Table 2. Effect of Various 5-HT Receptor Antagonists and the $\mathrm{D}_{\text {2like }}$ Receptor Antagonist Haloperidol Alone or in Combination with LSD $(0.1 \mathrm{mg} / \mathrm{kg})$ on Mean Baseline Startle Amplitudes in Sprague-Dawley Rats. ${ }^{*} p<.05$ vs. Veh/Veh Group

\begin{tabular}{|c|c|c|c|c|c|}
\hline Study & Treatment & Startle & Study & Treatment & Startle \\
\hline MDL 100,907 (0.5 mg/kg) & $\begin{array}{l}\text { Veh/Veh } \\
\text { MDL/Veh } \\
\text { Veh/LSD } \\
\text { MDL/LSD }\end{array}$ & $\begin{array}{l}315 \pm 62 \\
324 \pm 36 \\
204 \pm 25^{*} \\
201 \pm 35^{*}\end{array}$ & $(+)$-WAY 100,135 (1 mg/kg) & $\begin{array}{l}\text { Veh/Veh } \\
\text { WAY/Veh } \\
\text { Veh/LSD } \\
\text { WAY/LSD }\end{array}$ & $\begin{array}{l}247 \pm 43 \\
272 \pm 42 \\
170 \pm 12 \\
236 \pm 54\end{array}$ \\
\hline MDL 100,907 (1 mg/kg) & $\begin{array}{l}\text { Veh/Veh } \\
\text { MDL/Veh } \\
\text { Veh/LSD } \\
\text { MDL/LSD }\end{array}$ & $\begin{array}{l}219 \pm 31 \\
308 \pm 50 \\
225 \pm 36 \\
288 \pm 42\end{array}$ & $(+)$-WAY 100,135 (20 mg/kg) & $\begin{array}{l}\text { Veh/Veh } \\
\text { WAY/Veh } \\
\text { Veh/LSD } \\
\text { WAY/LSD }\end{array}$ & $\begin{array}{l}459 \pm 78 \\
544 \pm 95 \\
350 \pm 53 \\
431 \pm 62\end{array}$ \\
\hline SB 242,084 (0.5 mg/kg) & $\begin{array}{l}\text { Veh/Veh } \\
\text { SB/Veh } \\
\text { Veh/LSD } \\
\text { SB/LSD }\end{array}$ & $\begin{array}{l}346 \pm 38 \\
628 \pm 114^{*} \\
172 \pm 29 \\
210 \pm 18\end{array}$ & Haloperidol $(0.1 \mathrm{mg} / \mathrm{kg})$ & $\begin{array}{l}\text { Veh/Veh } \\
\text { Hal/Veh } \\
\text { Veh/LSD } \\
\text { Hal/LSD }\end{array}$ & $\begin{array}{l}395 \pm 91 \\
187 \pm 41^{*} \\
305 \pm 83 \\
220 \pm 41^{*}\end{array}$ \\
\hline SDZ SER 082 (1 mg/kg) & $\begin{array}{l}\text { Veh/Veh } \\
\text { SDZ/Veh } \\
\text { Veh/LSD } \\
\text { SDZ/LSD }\end{array}$ & $\begin{array}{l}523 \pm 106 \\
369 \pm 74 \\
322 \pm 65^{*} \\
191 \pm 28^{*}\end{array}$ & Haloperidol (0.2 mg/kg) & $\begin{array}{l}\text { Veh/Veh } \\
\text { Hal/Veh } \\
\text { Veh/LSD } \\
\text { Hal/LSD }\end{array}$ & $\begin{array}{l}434 \pm 94 \\
245 \pm 51^{*} \\
199 \pm 26^{*} \\
166 \pm 24^{*}\end{array}$ \\
\hline Ro 04-6790 (30 mg/kg) & $\begin{array}{l}\text { Veh/Veh } \\
\text { Ro/Veh } \\
\text { Veh/LSD } \\
\text { Ro/LSD }\end{array}$ & $\begin{array}{l}188 \pm 29 \\
190 \pm 32 \\
233 \pm 42 \\
161 \pm 30\end{array}$ & & & \\
\hline
\end{tabular}

242084 was without any effect on this measure. Pretreatment with MDL 100907 completely blocked the locomotor hyperactivity induced by $\operatorname{LSD}\left(\mathrm{F}_{1,28}=7.1, p<\right.$ .05). In contrast, pretreatment with SB 242084 was without effect $\left(\mathrm{F}_{1,28}=1.6, \mathrm{NS}\right)$.

\section{DISCUSSION}

With the exception of locomotor hyperactivity, the various behaviors produced by LSD were comparable to those reported with other related hallucinogens such as DOI. Thus, like DOI, LSD produced a robust disruption of PPI in both Wistar and Sprague-Dawley rats (Sipes and Geyer 1994 1995; Varty and Higgins 1995; Padich et al. 1996) and induced a range of behaviors including wet-dog shakes, back muscle contractions and forepaw treading (Pranzatelli 1990; Fone et al. 1991; Wettstein et al. 1999). However, unlike DOI which has a high selectivity for $5-\mathrm{HT}_{2}$ receptor populations, LSD interacts with other 5-HT (e.g., 5- $\mathrm{HT}_{1 \mathrm{~A}}, 5-\mathrm{HT}_{2 \mathrm{~A} / \mathrm{B} / \mathrm{C}}, 5-\mathrm{HT}_{6}$ ) and dopamine $\mathrm{D}_{2 \text { like }}$ receptors (Creese et al. 1975; Plassat et al. 1992; Shen et al. 1993; Boess et al. 1997; Aghajanian and Marek 1999). One aim of this study was therefore to clarify the possible contribution of these various receptors in the mediation of the behavioral effects of LSD, particularly the disruptive effects of this hallucinogen on PPI, which to the best of our knowledge has yet to be characterized.

In line with previous findings (Geyer 1998), administration of LSD to rats induced a dose-dependent disruption of PPI. Interestingly, pretreatment with the selective $5-\mathrm{HT}_{2 \mathrm{~A}}$ receptor antagonist MDL 100907 was able to prevent these effects. Selective blockade of $5-\mathrm{HT}_{2 \mathrm{~A}}$ receptors also completely blocked the locomotor stimulant effects of LSD. It is unlikely that the blockade of LSD-induced locomotor hyperactivity by MDL 100907 is related to non-specific effects. Firstly, animals pretreated with MDL 100907 alone were relatively more active than controls during the peak hyperactivity induced by LSD (10-25-min intervals, Figure 4). Secondly, we have previously found that MDL 100907 at the same dose $(0.5 \mathrm{mg} / \mathrm{kg})$ has no effect on the spontaneous activity of rats in a novel environment (Higgins et al. 2001; see also Moser et al. 1996). Collectively these findings strongly suggest that activation of $5-\mathrm{HT}_{2 \mathrm{~A}}$ receptors is the principal mechanism underlying the PPI deficits and locomotor hyperactivity observed with LSD. Blockade of 5- $\mathrm{HT}_{2 \mathrm{~A}}$ receptors also enhanced basal PPI, suggesting some degree of endogenous 5-HT tone at the $5-\mathrm{HT}_{2 \mathrm{~A}}$ receptor that reduces sensorimotor gating. However, this facilitation could only be seen under a condition in which the basal level of PPI was low (Figure 2, Panel A), and therefore would suggest that variations in basal PPI levels observed across experiments may be in part related to changes in endogenous 5-HT tonicity. Local infusion of MDL 100907 into the ventral pallidum was reported to increase basal PPI (Sipes and Geyer 1997); it is therefore possible that this site may be one of the brain areas mediating the PPI facilitation observed following systemic administration of MDL 100907.

Despite a high affinity of LSD for $5-\mathrm{HT}_{2 \mathrm{C}}$ receptors, which is of a similar order to that at the $5-\mathrm{HT}_{2 \mathrm{~A}}$ receptor (Egan et al. 1998; Porter et al. 1999), they do not appear to contribute to the observed behavioral effects of this 
A WAY $100135(1 \mathrm{mg} / \mathrm{kg})$

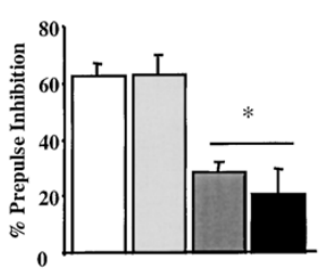

D SDZ SER $082(1 \mathrm{mg} / \mathrm{kg})$

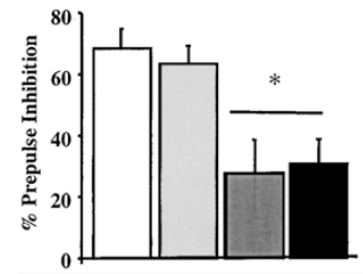

B WAY $100135(20 \mathrm{mg} / \mathrm{kg})$

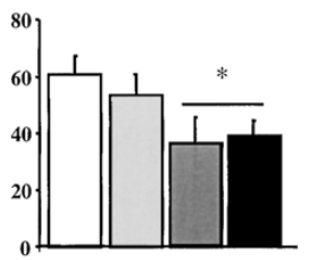

C $\quad$ RO 04-6790 $(30 \mathrm{mg} / \mathrm{kg})$

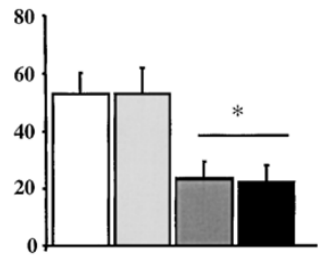

E Haloperidol $(0.1 \mathrm{mg} / \mathrm{kg})$

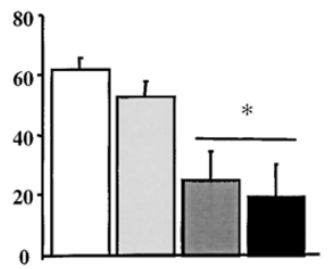

F Haloperidol $(0.2 \mathrm{mg} / \mathrm{kg})$

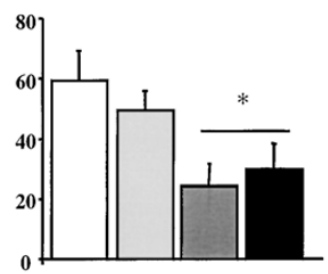

Figure 3. Effects of (+)-WAY 100135 (1 and $20 \mathrm{mg} / \mathrm{kg}$, s.c.), Ro 04-6790 (30 mg/kg, i.p.), SDZ SER 082 (1 mg/kg, s.c.) and haloperidol $(0.1$ and $0.2 \mathrm{mg} / \mathrm{kg}$, s.c.) on the disruption of PPI induced by LSD (0.1 mg/kg, s.c.) in Sprague-Dawley rats. Open bars: vehicle/vehicle treatments; gray bars: drug/vehicle treatments; crossed bars: vehicle/LSD treatments; black bars: drug/LSD treatments. Values represent mean \pm S.E.M. for each group. $\mathrm{n}=6-8$ per group. ${ }^{*} p<.05$, significantly different from vehicle-treated animals.

drug. For instance, at none of the doses of LSD tested were any behavioral signs ascribed to $5-\mathrm{HT}_{2 \mathrm{C}}$ receptor activation such as penile grooming/erections and hypoactivity observed (Kennett et al. 1997; Millan et al. 1997; Martin et al. 1998). Rather, LSD evoked a range of behavioral changes (wet-dog shakes, back muscle contractions, forepaw treading) that are attributed to $5-\mathrm{HT}_{2 \mathrm{~A}}$ receptor activation (Wettstein et al. 1999, Sánchez and Arnt 2000). Furthermore, the $5-\mathrm{HT}_{2 \mathrm{C}}$ antagonist SB 242084 at a dose of $0.5 \mathrm{mg} / \mathrm{kg}$ failed to antagonize the locomotor stimulant effect of LSD. This antagonist blocks the locomotor hypoactivity induced by the preferential $5-\mathrm{HT}_{2 \mathrm{C}}$ agonist $\mathrm{mCPP}$, with an approximate $\mathrm{ED}_{50}$ of $0.1 \mathrm{mg} / \mathrm{kg}$ (unpublished findings; see also Kennett et al. 1997). Furthermore, we have recently shown that SB 242084 at the dose of $0.5 \mathrm{mg} / \mathrm{kg}$ completely reverses several of the behavioral effects of the $5-\mathrm{HT}_{2 \mathrm{C}}$ agonist Ro 60-0175 (Grottick et al. 2000; Higgins et al. 2001). Hence, the failure of this antagonist to prevent the locomotor stimulant effects of LSD strongly argues against an involvement of $5-\mathrm{HT}_{2 \mathrm{C}}$ receptors in mediating the behavioral effects of LSD. As with the locomotor stimulant effects of LSD, the disruption of PPI was not affected by blockade of $5-\mathrm{HT}_{2 \mathrm{C}}$ receptors. The $5-\mathrm{HT}_{2 \mathrm{C}}$ antagonists, SDZ SER 082 or SB 242084, each administered at behaviorally active doses (Nozulak et al. 1995; Kennett et al. 1997; Mora et al. 1997; Grottick et al. 2000) failed to attenuate the PPI deficits induced by LSD. These findings are consistent with those reported by Sipes and Geyer (1995) showing that SDZ SER 082 was ineffective in normalizing the PPI deficits induced by DOI. Furthermore,
$\mathrm{mCPP}$ was found to reduce startle reactivity without affecting basal PPI (Sipes and Geyer 1994). Taken together, these findings strongly suggest that the $5-\mathrm{HT}_{2 \mathrm{C}}$ receptor may not be involved in the modulation of sensorimotor inhibitory processes. It is worth noting that SB 242,084 significantly increased basal startle response, which together with the inhibitory effects of mCPP on this measure suggests that $5-\mathrm{HT}_{2 \mathrm{C}}$ receptor modulation may influence startle reactivity. In the current study LSD significantly decreased basal startle, although pretreatment with SB 242,084 failed to prevent this effect, again suggesting that $\mathrm{LSD}$ acted via $5-\mathrm{HT}_{2 \mathrm{C}}$ independent receptor mechanisms to influence this measure. Finally, the negative data obtained with SDZ SER 082, which is also a high affinity $5-\mathrm{HT}_{2 \mathrm{~B}}$ receptor antagonist (Nozulak et al. 1995), makes it unlikely that this receptor subtype is involved in the effects of LSD on startle reactivity and sensorimotor gating.

We also failed to find any evidence for $5-\mathrm{HT}_{1 \mathrm{~A}}$ or $5-\mathrm{HT}_{6}$ receptors in the disruptive effects of LSD on PPI. Pretreatment with behaviorally active doses $(1 \mathrm{mg} / \mathrm{kg}$ : Forster et al. 1995; $20 \mathrm{mg} / \mathrm{kg}$ : Sipes and Geyer 1995) of the selective $5-\mathrm{HT}_{1 \mathrm{~A}}$ receptor antagonist, (+)WAY 100135, were without effect on the PPI deficits induced by LSD. This is an important observation as direct 5- $\mathrm{HT}_{1 \mathrm{~A}}$ receptor agonists (e.g., 8-OH-DPAT) have been reported to disrupt PPI (Rigdon and Weatherspoon 1992; Sipes and Geyer 1995). LSD also has a high affinity for 5- $\mathrm{HT}_{6}$ receptors (Boess et al. 1997); however, pretreatment with a behaviorally active dose of the selective 5- $\mathrm{HT}_{6}$ receptor antagonist, RO 04-6790 (Sleight et 

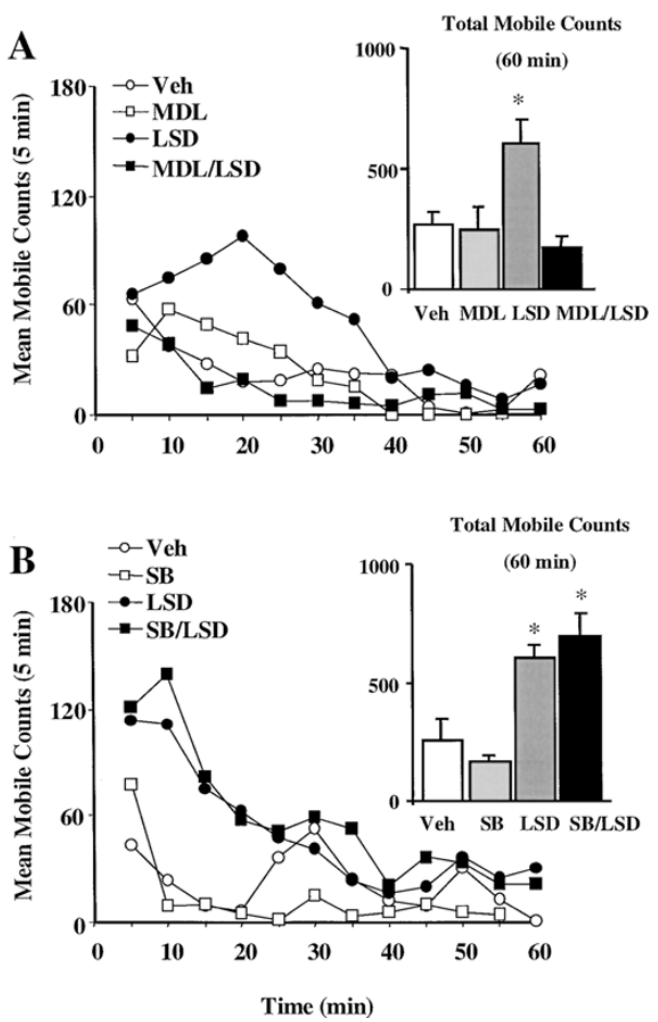

Figure 4. Effects of MDL 100907 (0.5 mg/kg, s.c.)and SB $242084(0.5 \mathrm{mg} / \mathrm{kg}$, i.p.) on the locomotor activity induced by LSD $(0.1 \mathrm{mg} / \mathrm{kg}$, s.c.) in Sprague-Dawley rats. Open bars: vehicle/vehicle treatments; gray bars: drug/vehicle treatments; crossed bars: vehicle/LSD treatments; black bars: drug/LSD treatments. Values represent mean \pm S.E.M. for each group. $\mathrm{n}=6-8$ per group. ${ }^{*} p<.05$, significantly different from vehicle-treated animals.

al. 1998; Bentley et al. 1999), failed to antagonize the disruption of PPI induced by LSD. It is therefore unlikely that $5-\mathrm{HT}_{6}$ receptors are involved in the disruptive effects of LSD on PPI.

The blockade of $\mathrm{DA}_{2 \text { like }}$ receptors was also without any effect on the PPI deficit induced by LSD. The lowest dose of haloperidol $(0.1 \mathrm{mg} / \mathrm{kg})$ we used was previously shown to block the disruption of PPI induced by apomorphine (Mansbach et al. 1988; Rigdon and Viik 1991; Swerdlow and Geyer 1993; Varty and Higgins 1995). Furthermore, no attenuation of an LSD-induced PPI deficit was observed following pretreatment with a higher dose $(0.2 \mathrm{mg} / \mathrm{kg})$ of haloperidol. These data are consistent with the observations of Varty and Higgins (1995) that a DOI-induced PPI disruption was insensitive to the $\mathrm{DA}_{2 \text { like }}$ receptor antagonists haloperidol and raclopride. Similarly, Padich et al.(1996) failed to reverse a DOI-induced auditory- and visual-PPI deficit with haloperidol $(0.25 \mathrm{mg} / \mathrm{kg})$. Taken together with the present findings with LSD, it would seem that $5-\mathrm{HT}_{2 \mathrm{~A}}$ receptor activation disrupts PPI through a DAergicindependent mechanism (possibly glutamatergic; see
Aghajanian and Marek 1999 2000). Notably, these three studies utilized both Wistar and Sprague-Dawley rat strains. However, research by Sipes and Geyer (1994) suggest that a DOI-induced disruption is blocked by haloperidol, although a direct effect of haloperidol at $5-\mathrm{HT}_{2 \mathrm{~A}}$ receptors could not be excluded (see discussion, Sipes and Geyer 1994). Clearly, a more thorough evaluation involving multiple rat strains and highly subtype selective DA antagonists against DOI and LSD-induced PPI disruptions are necessary to ultimately clarify any role of DA systems in 5- $\mathrm{HT}_{2 \mathrm{~A}}$ agonist-induced PPI disruptions. An alternative approach might be to evaluate the potency of DOI and/or LSD PPI disruptions in the various lines of DA receptor knockout mice presently available, which seem to show normal baseline PPI (Ralph et al. 1999).

Finally, it should be stressed that LSD interacts with other 5-HT receptors including $5-\mathrm{HT}_{5}$ and $5-\mathrm{HT}_{7}$, and it is thus possible that they too may contribute to its behavioral effects. For instance, it was recently found that the stimulatory effect of LSD on exploratory activity was attenuated in mice lacking $5-\mathrm{HT}_{5 \mathrm{~A}}$ receptors, thus indicating that the former receptors may be involved in the psychostimulant effects of LSD (Grailhe et al. 1999). However, it must be noted that LSD-induced PPI disruption was completely blocked by MDL 100907, which has a relatively low affinity for $5-\mathrm{HT}_{7}$ receptors $(1 \mathrm{nM}$

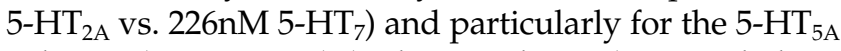
subtype $(>10,000 \mathrm{nM})$ (Kehne et al. 1996). Nonetheless, the respective contribution of $5-\mathrm{HT}_{5}$ and $5-\mathrm{HT}_{7}$ receptor subtypes in mediating the effects of LSD on PPI would need to be formally studied, once selective antagonists of these receptors become generally available.

Finally, the present study addressed strain differences in the behavioral effects of LSD. It has previously been reported that Sprague-Dawley and Wistar rats display differential sensitivities to PPI disruption induced by psychotomimetics such as apomorphine, amphetamine and PCP (Rigdon 1990; Varty and Higgins 1994; Kinney et al. 1999). The ability of antipsychotics (clozapine and risperidone) to reverse apomorphine- or dizocilpine-induced deficits also appears to differ between these two strains (Swerdlow et al. 1998; Varty et al. 1999). In the present study we found that LSD was equally disruptive in both rat strains. Interestingly, it was recently shown that reversal of dizocilpine-induced deficits in PPI with the 5- $\mathrm{HT}_{2 \mathrm{~A}}$ antagonist MDL 100907 did not differ betweeen Sprague-Dawley and Wistar rats (Varty et al. 1999). It may be that although inter-strain differences exist with respect to drugs acting through DA receptors, Sprague-Dawley and Wistar rats do not differ significantly in their response to agents acting primarily via $5-\mathrm{HT}_{2 \mathrm{~A}}$ receptors. Consistent with this suggestion, we found that LSD had similar effects on locomotor activity in Sprague-Dawley and Wistar rats, and that the incidence of the number of 
$5-\mathrm{HT}_{2 \mathrm{~A}}$ receptor-mediated behaviors (wet-dog shakes, forepaw treading and chewing) evoked by LSD was comparable in both strains. The only obvious difference was a marked increase in the number of back muscle contractions elicited by a dose of $0.3 \mathrm{mg} / \mathrm{kg}$ LSD in Sprague-Dawley rats.

In conclusion, the present study suggests that LSDinduced PPI disruption and locomotor changes are mediated via $5-\mathrm{HT}_{2 \mathrm{~A}}$ receptor activation. LSD also produces a number of other behaviors characteristic of $5-\mathrm{HT}_{2 \mathrm{~A}}$ receptor agonism such as wet-dog shakes, forepaw treading and back muscle contractions. These behavioral effects of LSD, with the exception of locomotor hyperactivity, are similar to those previously reported with other related hallucinogens such as DOI, most likely because both hallucinogens share a common mechanism of action at $5-\mathrm{HT}_{2 \mathrm{~A}}$ receptors.

\section{ACKNOWLEDGMENTS}

We would like to thank Juergen Wichmann and Phillippe Guerry for the synthesis of SB242,084 and MDL 100,907 respectively.

\section{REFERENCES}

Adams LM, Geyer MA (1982): LSD-Induced alteration of locomotor patterns and exploration in rats. Psychopharmacology 77:179-185

Aghajanian GK, Marek GJ (1999): Serotonin and hallucinogens. Neuropsychopharmacology 21:16S-23S

Aghajanian GK, Marek GJ (2000): Serotonin model of schizophrenia: emerging role of glutamate mechanisms. Brain Res Rev 31:302-312

Barnes NM, Sharp T (1999): A review of central 5-HT receptors and their function. Neuropharmacology 38:1083-1152

Bentley JC, Bourson A, Boess FG, Fone KC, Marsden CA, Petit N, Sleight AJ (1999): Investigation of stretching behaviour induced by selective $5-\mathrm{HT}_{6}$ receptor antagonist, Ro 04-6790, in rats. Br J Pharmacol 126:1537-1542

Boess FG, Monsma FJ, Carolo C, Meyer V, Rudler A, Zwingelstein C, Sleight AJ (1997): Functional and radioligand binding characterization of $5-\mathrm{HT}_{6}$ receptor stably expressed in HEK293 cells. Neuropharmacology 36:713-720

Bromidge SM, Duckworth M, Forbes IT, Ham P, King FD, Thewlis KM, Blaney FE, Naylor CB, Blackburn TP, Kennett GA, Wood MD, Clarke SE (1997): 6-Chloro-5-methyl-1 [[2-[(2-methyl-3piridyl)oxy]-5-pyridil]carbamoyl]-indoline (SB-242084): the first selective and brain penetrant $5-\mathrm{HT}_{2 \mathrm{C}}$ receptor antagonist. J Med Chem 40:3494-3496

Creese I, Burt DR, Snyder SH (1975): The dopamine receptor: differential binding of d-LSD and related agents to agonist and antagonist states. Life Sci 17:1715-1719

Egan CT, Herrick-Davis K, Miller K, Glennon RA, Teitler M (1998): Agonist activity of LSD and lisuride at cloned
$5 \mathrm{HT}_{2 \mathrm{~A}}$ and $5 \mathrm{HT}_{2 \mathrm{C}}$ receptors. Psychopharmacology 136 : 409-414

Fiorella D, Rabin RA, Winter JC (1995): The role of 5- $\mathrm{HT}_{2 \mathrm{~A}}$ and $5-\mathrm{HT}_{2 \mathrm{C}}$ receptors in the stimulus effects of hallucinogenic drugs I: antagonist correlation analysis. Psychopharmacology 121:347-356

Fone KCF, Robinson AJ, Marsden CA (1991): Characterization of the 5-HT receptor suptypes involved in the motor behaviours produced by intrathecal administration of 5-HT agonists in rats. Br J Pharmacol 103:1547-1555

Forster EA, Cliffe IA, Bill DJ, Dover GM, Jones D, Reilly Y, Fletcher A (1995): A pharmacological profile of the selective silent 5- $\mathrm{HT}_{1 \mathrm{~A}}$ receptor antagonist, WAY-100635. Eur J Pharmacol 281:81-88

Geyer MA (1998): Behavioral studies of hallucinogenic drugs in animals: Implications for schizophrenia research. Pharmacopsychiatry 31:73-79

Grailhe R, Waeber C, Dulawa SC, Hornung JP, Zhuang X, Brunner D, Geyer MA, Hen R (1999): Increased exploratory activity and altered response to LSD in mice lacking the $5-\mathrm{HT}_{5 \mathrm{~A}}$ receptor. Neuron 22:581-591

Grottick AJ, Fletcher PJ, Higgins GA (2000): Studies to investigate the role of $5-\mathrm{HT}_{2 \mathrm{C}}$ receptors on cocaine- and foodmaintained behavior. J Pharmacol Exp Ther 295:11831191

Higgins GA, Ouagazzal AM, Grottick AJ (2001): Influence of the $5-\mathrm{HT}_{2 \mathrm{C}}$ receptor antagonist SB242,084 on behaviour produced by the 5- $\mathrm{HT}_{2}$ agonist Ro 60-0175 and the indirect 5-HT agonist dexfenfluramine. Br J Pharmacol 133:459-466

Hitchcock JM, Lister S, Fischer TR, Wettstein JG (1997): Disruption of latent inhibition in the rat by the $5-\mathrm{HT}_{2}$ agonist DOI: effects of MDL 100,907, clozapine, risperidone and haloperidol. Behav Brain Res 88:43-49

Kehne JH, Baron BM, Carr AA, Chaney SF, Elands J, Feldman DJ, Frank RA, van Giersbergen PL, McCloskey TC, Johnson MP, Mccarty DR, Poitot M, Senyah Y, Siegel BW, Widmaier C (1996): Preclinical characterization of the potential of the putative atypical antipsychotic MDL 100,907 as a potent $5-\mathrm{HT}_{2 \mathrm{~A}}$ antagonist with a favorable CNS safety profile. J Pharmacol Exp Ther 277:968-981

Kennett GA, Wood MD, Bright F, Trail B, Riley G, Holland V, Avenell KY, Stean T, Upton N, Bromidge S, Forbes IT, Brown AM, Middlemiss DN, Blackburn TP (1997): SB 242084, a selective and brain penetrant 5- $\mathrm{HT}_{2 \mathrm{C}}$ receptor antagonist. Neuropharmacology 36:609-620

Kinney GG, Wilkinson LO, Saywell KL, Tricklebank MD (1999): Rat strain differences in the ability to disrupt sensorimotor gating are limited to dopaminergic system, specific to prepulse inhibition, and related to changes in startle amplitude or nucleus accumbens dopamine receptor sensitivity. J Neurosci 19:5644-5653

Krebs-Thomson K, Paulus MP, Geyer MA (1998): Effects of hallucinogens on locomotor and investigatory activity and patterns: influence of $5-\mathrm{HT}_{2 \mathrm{~A}}$ and $5-\mathrm{HT}_{2 \mathrm{C}}$ receptors. Neuropsychopharmacology 18:339-351

Mansbach RS, Geyer MA, Braff DL (1988): Dopaminergic stimulation disrupts sensorimotor gating in the rat. Psychopharmacology 94:507-514

Martin JR, Bös M, Jenck F, Moreau J-L, Mutel V, Sleight AJ, Wichmann J, Andrews JS, Berendsen HHG, Broekkamp 
CLE, Ruigt GSF, Köhler C, van Delft AML (1998): $5-\mathrm{HT}_{2 \mathrm{C}}$ receptor agonists: pharmacological characteristics and therapeutic potential. J Pharmacol Exp Ther 286: 913-924

Millan MJ, Peglion J-L, Lavielle G, Perrin-Monneyron S (1997): $5-\mathrm{HT}_{2 \mathrm{C}}$ receptors mediate penile erections in rats: actions of novel and selective agonists and antagonists. Eur J Pharmacol 325:9-12

Mittman SM, Geyer MA (1991): Diissociation of multiple effects of acute LSD on exploratory behavior in rats by ritanserin and propranolol. Psychopharmacology 105:69-76

Mora PO, Netto CF, Graeff FG (1997): Role of 5-HT $\mathrm{HA}_{2 \mathrm{~A}}$ and $5-\mathrm{HT}_{2 \mathrm{C}}$ receptor subtypes in the two types of fear generated by the elevated T-maze. Pharmacol Biochem Behav 58:1051-1057

Moser PC, Moran PM, Frank RA, Kehne JH (1996): Reversal of amphetamine-induced behaviours by MDL 100,907, a selective 5- $\mathrm{HT}_{2 \mathrm{~A}}$ antagonist. Behav Brain Res 73:163-167

Nelson DL, Lucaites VL, Wainscott DB, Glennon RA (1999): Comparisons of hallucinogenic phenylisopropylamine binding affinities at cloned human $5-\mathrm{HT}_{2 \mathrm{~A}}, 5-\mathrm{HT}_{2 \mathrm{~B}}$ and $5-\mathrm{HT}_{2 \mathrm{C}}$ receptors. Naunyn-Schmiedeberg's Arch Pharmacol 359:1-6

Nozulak J, Kalkman HO, Floersheim P, Hoyer D, Schoeffter P, Buerki HR (1995): (+)-cis-4,5,7,a,8,9,10,11,11a-octahydro7H-10-methylindolo[1,7-bc]-naphthyridine: a 5- $\mathrm{HT}_{2 \mathrm{C} / 2 \mathrm{~B}}$ receptor antagonist with low $5-\mathrm{HT}_{2 \mathrm{~A}}$ receptor affinity. $\mathrm{J}$ Med Chem 38:28-33

Padich RA, McCloskey TC, Kehne JH (1996): 5-HT modulation of auditory and visual sensorimotor gating: II. Effects of the $5-\mathrm{HT}_{2 \mathrm{~A}}$ antagonist MDL 100,907 on disruption of sound and light prepulse inhibition produced by 5-HT agonists in Wistar rats. Psychopharmacology 124:107-116

Palfreyman MG, Schmidt CJ, Sorensen SM, Dudley MW, Kehne JH, Moser P, Gittos MW, Carr AA (1993): Electrophysiological, biochemical and behavioral evidence for $5-\mathrm{HT}_{2}$ and $5-\mathrm{HT}_{3}$ mediated control of dopaminergic function. Psychopharmacology 112:S60-S67

Plassat JL, Boschert U, Amlaiky N, Hen R (1992): The mouse $5 \mathrm{HT}_{5}$ receptor reveals a remarkable heterogeneity within the 5HT1D receptor family. EMBOJ 11:4779-4786

Porter RHP, Benwell KR, Lamb H, Malcolm CS, Allen NH, Revell DF, Adams DR, Sheardown MJ (1999): Functional characterization of agonists at recombinant human $5-\mathrm{HT}_{2 \mathrm{~A}}, 5-\mathrm{HT}_{2 \mathrm{~B}}$ and $5-\mathrm{HT}_{2 \mathrm{C}}$ receptors in $\mathrm{CHO}-$ K1 cells. Br J Pharmacol 128:13-20

Pranzatelli MR (1990): Evidence for involvement of 5-HT2 and 5-HT1C receptors in the behavioral effects of the 5-HT agonist 1-(2,5-dimethoxy-4-iodophenylaminopropane)-2 (DOI). Neurosci Lett 115:74-80

Ralph RJ, Varty GB, Kelly MA, Wang Y-M, Caron MG, Rubinstein M, Grandy DK, Low MJ, Geyer MA (1999): The Dopamine $\mathrm{D}_{2}$, but not $\mathrm{D}_{3}$ or $\mathrm{D}_{4}$, receptor subtype is essential for the disruption of prepulse inhibition produced by amphetamine in mice. J Neurosci 19:4627-4633

Rigdon GC (1990): Differential effects of apomorphine on prepulse inhibition of acoustic startle reflex in two rats strains. Psychopharmacology 102:419-421

Rigdon GC, Viik K (1991): Prepulse inhibition as screening test for potential antipsychotics. Drug Dev Res 23:91-99
Rigdon GC, Weatherspoon JK (1992): 5-Hydroxytryptamine 1a-receptor agonists block prepulse inhibition of acoustic startle reflex. J Pharmacol Exp Ther 263:486-493

Roth BL, Willins DL, Kristiansen K, Kroeze WK (1999): Activation is hallucinogenic and antagonism is therapeutic: role of $5-\mathrm{HT}_{2 \mathrm{~A}}$ receptor in atypical antipsychotic drug actions. Neuroscientist 5:254-262

Sánchez C, Arnt J (2000): In vivo assessment of 5- $\mathrm{HT}_{2 \mathrm{~A}}$ and $5-\mathrm{HT}_{2 \mathrm{C}}$ antagonistic properties of newer antipsychotics. Behav Pharmacol 11:291-298

Schreiber R, Brocco M, Millan MJ (1994): Blockade of the discriminative stimulus effects of DOI by MDL 100,907 and the atypical antipsychotics, clozapine and risperidone. Eur J Pharmacol 264:99-102

Shen Y, Monsma FJ Jr, Metcalf MA, Jose PA, Hamblin MW, Sibley DR (1993): Molecular cloning and expression of 5-hydroxytryptamine7 serotonin receptor subtype. J Biol Chem 268:18200-18204

Sipes TA, Geyer MA (1994): Multiple serotonin receptor subtypes modulate prepulse inhibition of startle response in rats. Neuropharmacology 33:441-448

Sipes TE, Geyer MA (1995): DOI disruption of prepulse inhibition of startle in the rat is mediated by $5-\mathrm{HT}_{2 \mathrm{~A}}$ and not by $5-\mathrm{HT}_{2 \mathrm{C}}$ receptors. Behav Pharmacol 6:839-842

Sipes TE, Geyer MA (1997): DOI disrupts prepulse inhibition of startle in rats via $5-\mathrm{HT}_{2 \mathrm{~A}}$ receptors in the ventral pallidum. Brain Res 761:97-104

Sleight AJ, Boess FG, Bös M, Levet-Trafit B, Riemer C, Bourson A (1998): Characterization of Ro 04-6790 and Ro 630563: potent and selective antagonists at human and rat 5- $\mathrm{HT}_{6}$ receptors. Br J Pharmacol 124:556-562

Swerdlow NR, Geyer MA (1993): Clozapine and haloperidol in an animal model of sensorimotor gating deficits in schizophrenia. Pharmacol Biochem Behav 44:741-744

Swerdlow NR, Varty GB, Geyer MA (1998): Discrepant findings of clozapine effects on prepulse inhibition of startle: Is it the route or the rat? Neuropsychopharmacology 18:50-56

Titeler M, Lyon RA, Glennon RA (1988): Radioligand binding evidence implicates the brain $5-\mathrm{HT}_{2}$ receptors as a site of action for LSD and phenylisopropylamine hallucinogens. Psychopharmacology 94:213-216

Varty GB, Higgins GA (1994): Differences between three rat strains in sensitivity to prepulse inhibition of an acoustic startle response: influence of apomorphine and phencyclidine pretreatment. J Psychopharmacology 8: 148-156

Varty GB, Higgins GA (1995): Examination of drug-induced and isolation-induced disruptions of prepulse inhibition as model to screen antipsychotic drugs. Psychopharmacology 122:15-26

Varty GB, Bakshi VP, Geyer MA (1999): M100907, a serotonin $5-\mathrm{HT}_{2 \mathrm{~A}}$ receptor antagonist and putative antipsychotic, blocks dizocilpine-induced prepulse inhibition deficits in Sprague-Dawley and Wistar rats. Neuropsychopharmacology 20:311-321

Wettstein JG, Host M, Hitchckock JM (1999): Selectivity of action of typical and atypical antipsychotic drugs as antagonists of the behavioral effects of 1-[2,5-dimethoxy4-iodophenyl]2-aminopropane (DOI). Prog Neuro-psychopharmacol Biol Psychiat 23:533-544 